\title{
Effect of Stunting on Intelligence Quotient (IQ) of School-Age Children
}

\author{
Wahyu I.D. Aurora ${ }^{1, *}$ Rico J. Sitorus ${ }^{2}$, Rostika Flora ${ }^{3}$ \\ ${ }^{1}$ Public Health Departement Faculty of Medicine and Health Science Universitas Jambi \\ ${ }^{2}$ Epidemiology and Biostatistics Departement Faculty of Public Health Universitas Sriwijaya \\ ${ }^{3}$ Nutrition Department Faculty of Public Health Universitas Sriwijaya \\ *Corresponding author, email: auroradr@unja.ac.id
}

\begin{abstract}
The World Health Organization for Child Growth Standards estimates that at least one in four children under five years of age fails to grow optimally according to established standards. Nutritional status on height for the period under standard or stunting is a manifestation of malnutrition and is a severe health problem. This study analyzes the relationship between stunting on the intelligence quotient (IQ) of school-age children. This research is a quantitative study with the design used as observational analytic with an unmatching case-control. The sample consisted of 75 stunting cases and 75 control cases collected in August - October 2019 in Palembang City. The stunting variable analyzes the z-score in determining the categorical nutritional status. Interviewed with the respondent's mother to measure environmental sanitation, history of infection, breastfeeding, economic status, food intake, mother and father's education. The instrument for assessing student intelligence questions used the CPM (Colored Progressive Matrics) test. From the results of statistical show a significant relationship between stunting with Intelligence Quotient (IQ) in children $(\mathrm{p}=0.000$, OR: 4,57 (95\% CI:2,1733-9,6873). There are significant relationship between environment sanitation $(\mathrm{p}=$ 0,04 OR: 2,245 (95\% CI: 0,908-5,720), economic status ( $\mathrm{p}=0,009$ OR: 2,5 (95\% CI: 1,189-5,333) and food intake (p $=0,005$ OR: $2,82(95 \%$ CI: 1,271-6,398) and no significant relationship between the history of infection $(\mathrm{p}=0,841 \mathrm{OR}$ : 1,181 (95\% CI: 0,15-9,11), to the Intelligence Quotient (IQ) of school-age children. Children with stunting affect intelligence and have 5.2 times lower average intelligence quotient (IQ) than children who are not stunting after being controlled by confounding variables environmental sanitation, economic status, and food intake.
\end{abstract}

Keywords: Stunting, Intelligence Quotient, School-Age Children.

\section{INTRODUCTION}

Stunting is a condition of chronic malnutrition in children, identified by measuring child's length (for children less than two years) and height (for children age two years or older) and according to WHO Child Growth Standards, is under -2SD for stunted and -3SD for severely stunted [1]. Stunting makes children are short when compared to others. If this condition is left later, it will delay the child's development, and if this lasts a long time will affect his intelligence and school achievement [2]. Stunting is a nutritional problem in almost all countries in the world. Data from UNICEF states that the prevalence of stunting in the world is up to $28 \%$. In Southern Asia, 38\% and southern and eastern Africa are up 40\%(3). The stunting rate in South Sumatra Province ranks 10th after the province of North Kalimantan, with an incidence of $26.9 \%$ [4]. This number is very high and needs serious attention; several theories said stunting would persist in children over two years and significantly impact children's health.

Children's health needs children to meet to grow up well and develop optimally [5]. If the growth and development go very well from birth into school-age of course will be an intelligent life generation. Children's health includes physical, spiritual, and social healthrelated to disease and physical development, intellectual and emotional intelligence [6]. Unfortunately, only a few people research the effects that occur at school age. When 
the child in school age, the child with stunting suffers from chronic malnutrition and delayed growth and development processes for a long time, this condition will affect academic performance [7-8]. One way to assess the impact of stunting in school-age children is to consider their intellectual intelligence [6]. Children's brightness in elementary school is a beginning screening to improve their future because elementary school-age children are a strong foundation for further educational development. This study aimed to determine the effect of stunting on the intelligence of elementary school-age children.

\section{METHOD}

This quantitative study employed an unmatching case-control approach. It used primary data by stunting status, IQ test, exam result, and interviewing the respondents' mothers in August - October 2019 in Palembang, Indonesia. This study evaluated the causal relationship between stunting and intellectual intelligence, also measured other variables, such as infection history, environment sanitation, food intake, and economic status. The population of this study is all elementary school' children in Palembang. Sample 150 consisted of 75 stunting cases and 75 controls with a consecutive sampling technique. The inclusion criteria were elementary school children in three districts of Palembang (Sukarame, Seberang Ulu 1 dan Seberang Ulu 2). For the case group, ages 9-12 years are children with stunting (height-for-age Z-scores under -2SD), and for the control group is normal children (Z-scores -2SD until +2SD). The exclusion criteria are children with a history of congenital disabilities and growth disorders. The Stunting variable is measured using a microtome and then using software to analyze the z-score in determining the categorical nutritional status. Interviewed with respondent's mother to measure infection history, environment sanitation, food intake, economic status, and parents' education. The instrument for assessing student intelligence used the CPM (Colored Progressive Matrics) test, a tool specifically used to determine the brightness of children for ages 9-12 years. The measurement results were be read and categorized by a Psychologist. After the data is collected, then the data is analyzed using a computer program. Bivariate data analysis used chi-square and logistic regression for multivariate analysis. The study protocol was reviewed and approved by the Committee of Public Health Research Ethics Sriwijaya University (No. 273/UN9.1.10?KKE/2019).

\section{RESULT}

Table 1 describes the frequency distribution of respondents. Of 150 respondents, most respondents aged 11 years $(42.68 \%)$, male sex $(46.75 \%)$, stunting $(50 \%)$ had an average intellectual intelligence above $(54 \%)$, did not have a long history of infection (96\%), good environmental sanitation (80.67\%), have good food intake $(72 \%)$, good Sosial Economic (63.33\%).

Table 1. Distribution of respondents’ characteristics

\begin{tabular}{|l|c|c|}
\hline Variable & N & Percentage (\%) \\
\hline Ages & 74 & 49,3 \\
$9-10$ years & 78 & 50,7 \\
$11-12$ years & 70 & 46,75 \\
\hline Sex & 80 & 53,3 \\
Male & & \\
Female & 75 & 50 \\
\hline Stunting Status & 50 \\
Stunting & 75 & 54 \\
Normal & & 46 \\
\hline Intellectual Intelligence & 81 & 4 \\
Above Average & 69 & 96 \\
Under Average & 6 & \\
\hline History of infection & 144 & 80,67 \\
Yes & 121 & 19,33 \\
No & 29 & 72 \\
\hline Environment Sanitation & 108 & 28 \\
Good & 42 & 63,33 \\
Not Good & 95 & 36,67 \\
\hline Food Intake & \\
Good & 55 & \\
Not Good & \multicolumn{2}{|c|}{} \\
\hline Status Economic & & \\
High & \multicolumn{2}{|c|}{} \\
Low & \multicolumn{2}{|c|}{} \\
\hline
\end{tabular}


Tabel 2 shows that children with stunting who get an above average IQ value are $64 \%$ and get under average IQ score below 36\%. Normal children get an above average IQ score $72 \%$ and get below average IQ score are $28 \%$. From the results of statistical show, a significant relationship between stunting with intellectual intelligence in children ( $\mathrm{p}=0.000$, OR: 4,57 $(95 \%$ CI:2,1733-9,6873). Tabel 2 also showed a significant relationship between). There is significant relationship between environment sanitation ( $\mathrm{p}=0,04$ OR: 2,245 (95\% CI: 0,908-5,720), economic status ( $\mathrm{p}=0,009$ OR: $2,5$ (95\% CI: $1,189-5,333)$, food intake ( $\mathrm{p}=0,005$ OR: $2,82(95 \%$ CI: 1,271-6,398) and no significant relationship between the history of infection $(p=0,841$ OR: 1,181 (95\% CI: $0,15-9,11)$ to the Intelligence Quotient (IQ) of school-age children.

Table 2. Relationship of a dependent variable and independent variable

\begin{tabular}{|c|c|c|c|c|c|}
\hline \multirow{2}{*}{ Variable } & \multicolumn{2}{|c|}{ Intellectual Intelligence } & \multirow{2}{*}{ Amount } & \multirow{2}{*}{ OR* $\left(95 \% \mathrm{CI}^{* * *}\right)$} & \multirow{2}{*}{$\begin{array}{c}\mathrm{P}- \\
\text { value }\end{array}$} \\
\hline & Below A verage & Above A verage & & & \\
\hline $\begin{array}{l}\text { Stunting Status } \\
\text { Stunting } \\
\text { Normal }\end{array}$ & $\begin{array}{l}48(64 \%) \\
21(28 \%)\end{array}$ & $\begin{array}{l}27(36 \%) \\
54(72 \%)\end{array}$ & $\begin{array}{l}75 \\
75\end{array}$ & $\begin{array}{l}4,57(2,1733- \\
9,6873)\end{array}$ & 0.000 \\
\hline $\begin{array}{l}\text { History of infection } \\
\text { Yes } \\
\text { No }\end{array}$ & $\begin{array}{l}3(50 \%) \\
66(45,83 \%) \\
\end{array}$ & $\begin{array}{l}3(50 \%) \\
78(54,17 \%)\end{array}$ & $\begin{array}{l}6 \\
144 \\
\end{array}$ & $1,181(0,15-9,11)$ & 0.841 \\
\hline $\begin{array}{l}\text { Environment Sanitation } \\
\text { Not Good } \\
\text { Good } \\
\end{array}$ & $\begin{array}{l}18(62,07 \%) \\
51(42,15 \%)\end{array}$ & $\begin{array}{l}11(37,93 \%) \\
70(57,85 \%)\end{array}$ & $\begin{array}{l}29 \\
121 \\
\end{array}$ & $2,245(0,908-5,720)$ & 0,04 \\
\hline $\begin{array}{l}\text { Food Intake } \\
\text { Not Good } \\
\text { Good } \\
\end{array}$ & $\begin{array}{l}27(64,29 \%) \\
42(38,89 \%) \\
\end{array}$ & $\begin{array}{l}15(35,71 \%) \\
66(61,11 \%)\end{array}$ & $\begin{array}{l}42 \\
108 \\
\end{array}$ & $2,82(1,271-6,398)$ & 0,005 \\
\hline $\begin{array}{l}\text { Status Economic } \\
\text { Low } \\
\text { High }\end{array}$ & $\begin{array}{l}33(60 \%) \\
36(37,89 \%) \\
\end{array}$ & $\begin{array}{l}22(40 \%) \\
59(62,11 \%)\end{array}$ & $\begin{array}{l}55 \\
95 \\
\end{array}$ & $2,45(1,180-5,145)$ & 0,009 \\
\hline
\end{tabular}

Five variables have a p-value $<0.25$, which then enter into the multivariate analysis: stunting, exclusive breastfeeding, environmental sanitation, eating habits, and physical activity (Table 3 ). The variables are then further analysed with logistic regression until all variables enter as candidates for the intellectual intelligence model. The variables with a p-value $>0.05$ exclude using the Enter method start with the most significant $\mathrm{p}$-value. The variables included in the multivariate analysis were also assessed confounding variables with stratification analysis by comparing the OR values before and after variables exclude from the model.

Table 3. Variables included in multivariate analysis criteria

\begin{tabular}{|l|c|c|}
\hline \multicolumn{1}{|c|}{ Variable } & OR & P-value \\
\hline Stunting & 4,57 & 0,000 \\
Environment Sanitation & 2,24 & 0,040 \\
Food Intake & 2,85 & 0,005 \\
Status Economic & 2,45 & 0,009 \\
\hline
\end{tabular}

Subsequent logistic regression analysis is performed with the results as shown in table 5. The final model of the multivariate results found four variables: stunting, Exclusive breastfeeding, eating habits, and physical activity showed a significant relationship to the intelligence of elementary school-age children. The most dominant variable affecting school-age children's intelligence is stunting, with a p-value of $0,000(\mathrm{OR}=5,22$ CI: 2,233-9,998). Children with stunting have 4.7 times lower average intelligence than children who are not stunting after being controlled by the variable confounding, eating habits, status, economic and environmental sanitation. In final model, variable environmental sanitation ( $\mathrm{p}=0,008$, OR 2,9; 95\%CI: $1,323-6,363)$, food intake ( $\mathrm{p}=0,007$, OR 3,$17 ; 95 \% \mathrm{CI}$ $1,376-7,302)$ and status economic $(\mathrm{p}=0,028 ; 95 \% \mathrm{CI}$ : $1,098-5,265)$ ) were have significantly associated 
Table 4. Final Model of Logistic Regression

\begin{tabular}{|c|c|c|c|c|c|c|}
\hline \multirow[b]{2}{*}{ Variable } & \multirow[b]{2}{*}{ Coefficient } & \multirow{2}{*}{$\begin{array}{l}\text { Std. } \\
\text { Err } \\
\text { or }\end{array}$} & \multirow[b]{2}{*}{ P-value } & \multirow[b]{2}{*}{ OR } & \multicolumn{2}{|c|}{ CI } \\
\hline & & & & & Low & High \\
\hline Stunting & 1,555 & 1,80 & 0,000 & 5,2 & 2,233 & 9,998 \\
\hline Environmental Sanitation & 1,065 & 1,16 & 0,008 & 2,90 & 1,323 & 6,363 \\
\hline Food Intake & 1,154 & 1,34 & 0,007 & 3,17 & 1,376 & 7,302 \\
\hline Status Economic & 0,877 & 0,96 & 0,028 & 2,40 & 1,098 & 5,265 \\
\hline
\end{tabular}

\section{DISCUSSION}

The significance of this research shows that stunting is a risk factor for below-average intelligence of elementary school-age children. The stunting detected in children has reached primary school age; of course, chronic malnutrition has occurred a long time ago or maybe even in pregnancy. The deficiency of nutrition at a certain level can cause brain weight, cell number, cell size, and other biochemical substances lower than normal children. The more extended child is affected by malnutrition, the more severe it will cause [9]. Stunting is a growth disorder that can indicate interference with the body's organs. One of the organs that most quickly damaged by malnutrition is the brain. The brain is a nerve centre closely related to the child's response to seeing, hearing, thinking, and doing movements [10].

According to previous research, malnutrition in childhood will cause their intellectual level to decrease by 10-15 IQ points, with the risk of not adopting science. Besides, even the power of thought will be fragile due to deficiency or lack of various micron nutrients such as iodine, Fe, and PEM [5]. The results of this study are in line with previous research that there is a strong relationship between malnutrition and IQ in children, where $82.9 \%$ of the stunted children studied have an IQ test result that is not optimal [11].

Compared with similar research, this research is not in line, which states there is no difference in intelligence Question (IQ) between stunting and non-stunting. [11]. According to the study, intelligence relations are more influential in children with low energy consumption levels, differences, and $\mathrm{Fe}$ consumption. According to the theory, stunting will cause brain development that is not optimal. In this study, there is no relationship between stunting and IQ intelligence caused by several factors, for example, at the time of measurement, samples that cannot be generalized, and other socio-cultural factors. But the results mentioning deficiency of energy protein and $\mathrm{Fe}$ strengthen that long-term malnutrition will affect one's intelligence.

According to previous research that there is a relationship between environmental health factors with IQ tests. Environmental health does not affect intelligence internally, but the impact caused by poor sanitation can hurt health, especially in the long term.
Poor sanitation also impacts children's cognitive development at an early age [12].

This research has a limitation that is the determination of intelligence variables in this study using only one measuring instrument using the CPM test. That cannot be the only benchmark in assessing children's intelligence, as in various theories that state that children's intelligence is not just intellectual but also includes emotional, linguistic, logical, intrapersonal, musical, spatial, and naturalist.

\section{CONCLUSION}

There is an effect of stunting on elementary schoolage children's intelligence with a p-value of 0,000 $(\mathrm{OR}=$ 5.2). Children who suffer from stunting have a 5.2 chance of getting lower average intelligence than children who are not stunting after being controlled by variables confounding, food intakes, economic status, environmental sanitation, and academics.

\section{ACKNOWLEDGMENT}

The authors would like to thanks Kamaludin, Yuli Hartati, Muhamad Uyun, and Zulkarnain for their support in this study. The authors are also grateful to Erma Yani for a psychologist who has done intelligence tests on children.

\section{REFERENCES}

[1] M. de Onis, F. Branca. Childhood stunting: a global perspective. Maternal \& Child Nutrition. 2016;12(S1):12-26.

[2] D. W. Dewey, K. Begum. Long-term consequences of stunting in early life. Maternal \& Child Nutrition. 2011;7(s3):5-18.

[3] UNICEF. United Nations International Children's Emergency Fund. Annual Report 2009 UNICEF Division Communication; New York, USA2009.

[4] RISKESDAS. Laporan Hasil Riset Kesehatan Dasar (RISKESDAS). In: KemenkesRI, editor. Jakarta: Badan Penelitian dan Pengembangan Kesehatan 2018.

[5] D. Kasdu . Anak cerdas: Niaga Swadaya; 2004 
[6] R. W. Kamphaus. Clinical assessment of child and adolescent intelligence: Springer; 2019.

[7] N. Devi. Gizi Anak Sekolah Jakarta: EGC; 2012.

[8] B. Asmare, Taddele, Berihun S, Wagnew F. Nutritional status and correlation with academic performance among primary school children, northwest Ethiopia. BMC Research Notes. 2018;11(1):805.

[9] Husaini YK, Sulaeman Z, Basuki SM, Karyadi D, Matulessy P, Samsudin. Outpatient rehabilitation of severe protein-energy malnutrition (PEM). Food and nutrition bulletin. 2016;8(2):1-6.

[10] Picauly I, Toy SM. Analisis determinan dan pengaruh stunting terhadap prestasi belajar anak Sekolah di Kupang dan Sumba Timur, NTT. Jurnal Gizi dan Pangan. 2013;8(1):55-62.

[11] Adedeji I, John C, Okolo S, Ebonyi A, Abdu H, Bashir M. Malnutrition and the Intelligence Quotient of Primary School Pupils in Jos, Nigeria. 2017.

[12] Freeman FN, Holzinger KJ, Mitchell BC. The influence of environment on the intelligence, school achievement, and conduct of foster children. Yearbook of the National Society for the Study of Education. 2015; Pt. I:102-217. 